\title{
АХИНЖАНОВ СЕРЖАН МУСАТАЕВИЧ: к 80-летию со дня рождения
}

\author{
(C) 2019 г. Т.В. Савельева
}

Сержан Мусатаевич Ахинжанов родился в 1939 г. в г. Алма-Ате. После окончания средней школы в 1957 г. поступил в Казахский государственный университет им. С.М. Кирова на исторический факультет, со второго курса он был переведен в Московский государственный университет им. М.В. Ломоносова на кафедру археологии. В 1964 г. Сержан Мусатаевич с отличием окончил исторический факультет Университета по специальности «археология». Наставником по специальности и руководителем дипломной работы был известный ученый Л.Р. Кызласов.

С.М. Ахинжанов продолжил обучение, поступив в аспирантуру при Институте истории, археологии и этнографии им. Ч.Ч. Валиханова АН Казахской ССР. В 1968 г., после окончания аспирантуры, молодой ученый был оставлен в ИИАЭ АН КазССР для работы в отделе средневековой истории. В 1969 году С.М. Ахинжанов был переведен в отдел археологии, где принимал активное участие в исследовании городища Отрар. В 1973 г. С.М. Ахинжанов защитил кандидатскую диссертацию на тему: «Кипчаки и их политическое взаимоотношение с Хорезмом в XI-XIII вв.». С 1984 г. Сержан Мусатаевич стал заведовать лабораторией археологической технологии.

Ключевые слова: археология, С.М. Ахинжанов, кыпчаки

В течение многих лет Сержан Мусатаевич возглавлял один из отрядов Южно-Казахстанской комплексной археологической экспедиции, проводил раскопки на городище Отрар. С 1982 по 1986 гг. руководил работами Шульбинской археологической экспедиции в Восточном Казахстане. С 1982 по 1991 гг. был начальником одной из крупных археологических экспедиций - ЦентральноКазахстанской.

В 1989 г. вышла его монография «Кыпчаки в истории средневекового Казахстана», которая принесла автору широкую известность в кругах на- учной общественности - археологов, историков, востоковедов СССР и за рубежом. Книга стала значительным событием в исследовании кыпчаков - народа, сыгравшего важную роль в политической, экономической и культурной жизни Евразии.

Велика была роль кыпчаков в этногенезе казахов и других тюркских народов: из среды кыпчаков вышли представители правящих династий Мамлюкского Египта; представители кыпчаков в XIII в. возглавляли Делийский султанат; кыпчаки принимали активное участие в жизни Хорезма и Руси, из кыпчаков форми- 
ровались крупные контингенты войск в Грузии, Венгрии, Хорезме. Важным событием их истории явилось создание в XII в. государства с центром в Сыгнаке. Кыпчакская проблема, таким образом, играет большую роль не только в жизни древних народов Казахстана и Средней Азии, но и в истории Восточной Европы.

Сержан Мусатаевич в своей монографии уделил большое место проблеме взаимодействия кыпчаков и Хорезма - части фундаментальной проблемы взаимодействия города и степи, земледелия и скотоводства. Он одним из первых поставил вопрос о так называемой степной цивилизации, дефиниция которой стала предметом дискуссий в науке особенно в последние годы. Талантливая многоплановая книга С.М. Ахинжанова опередила время и поэтому остается остро востребованной и сейчас, о чем свидетельствует факт ее нескольких переизданий - для научных работ случай достаточно редкий.

История кыпчаков средневекового Казахстана изучена неравномерно, хотя благодаря работам советских исследователей (историков, археологов, лингвистов, этнографов), многие вопросы в настоящее время получили объяснение в научной литературе. Большой вклад внесли в это дело А.Х. Маргулан, А.Н. Кононов, Л.П. Потапов, Н.А. Баскаков, С.Г. Агаджанов, Л.Р. Кызласов, Г.А. Федоров-Давыдов, С.А. Плетнева, Р.Г. Кузеев, Ю.А. Зуев, С.Г. Кляшторный, Б.Е. Кумеков, Ф.Х. Арсланова, Д.Г. Савинов, К.Ш. Шаниязов.

Наиболее исследованными можно считать вопросы, связанные с пребыванием кыпчаков в южнорусских степях в предмонгольское время, где они были известны окружающим их народам под именем половцев, их взаимоотношениями на протяжении более чем двухсотлетней истории с Древней Русью.

Прослежено время пребывания кыпчаков в составе государства кимаков, сложившегося к концу I тыс. н.э. в восточных пределах Казахстана. Большой интерес представляют процессы взаимодействия и взаимовлияния языков славянских и тюркских, в частности, кыпчакских племен и народов, находившихся в тесном общении в начале II тыс. н.э., на анализе тюркских лексических элементов «Слова о полку Игореве» - выдающегося памятника древнерусской литературы.

И все же следует отметить, что многие вопросы исторического прошлого кыпчакских племен, населявших основную территорию Казахстана, остаются еще не до конца раскрытыми. До сих пор неясно их происхождение, их взаимоотношения с племенами кимаков, а также с другими этносами, с которыми им приходилось сталкиваться, и государственными образованиями. Они, конечно, не могли не оставить заметного следа в общественной жизни и деятельности как кыпчакских племен, так и окружавших их народов и государственных образований, таких как Хорезм.

В своей монографии

C.M. Ахинжанов показал как велика роль кыпчаков в сложении казахской народности, ибо они являются одним из крупнейших компонентов в этногенезе казахов, а также сыграли важную роль в этногенезе других тюркоязычных народов. Об этом свидетельствует не только то обстоятельство, что даже для периода их ранней этнической истории имеются известия об их пребывании в более или менее разнящихся этнических 
коллективах (например, на Алтае, в Монголии, в Хорезме и других местах), а также то, что кыпчаки в качестве существенных этнических компонентов входили в состав современных тюркоязычных народов: узбеков, каракалпаков, киргизов, башкиров, туркмен, алтайцев и др.

Другое обстоятельство заключается в том, что все письменные источники, ставшие достоянием науки, использовались по отношению к этому народу весьма неравномерно как в историко-политическом, так и в территориальном аспектах. Следует отметить, что исследователи в первую очередь обращали и в основном обращают внимание только на известия, которые могли бы пролить свет на историю западных кыпчаков, иначе именуемых в европейских хрониках команами, а в русских летописях - половцами. Такие исследования, прежде всего, служили дополнением к написанию истории Древней Руси, Венгрии, Византии, тюркоязычных племен и народов Южной Сибири, причем, кыпчако-половецкий материал был лишь иллюстрацией к тому или иному историческому эпизоду из жизни указанных государств и народов.

В последние 20 лет интерес к проблеме кыпчаков в восточной части Евразийских степей резко повысился, о чем свидетельствуют работы археологов, историков, этнографов научных учреждений Казахстана и Южной Сибири, Санкт-Петербурга и Средней Азии.

Б.Е. Кумеков на основе тщательного источниковедческого анализа историко-географических сведений, содержащихся в средневековых арабо- и персоязычных сочинениях IXXI вв., исследует историю кимаков - племени, которое на определенном историческом отрезке времени имело теснейшие связи с кыпчакскими племенами настолько близкие, что почти все современные исследователи, включая и самого Б.Е. Кумекова, считают, что кимаки и кыпчаки - это один и тот же этнический коллектив. Автор «реконструирует» основные этапы сложения и развития кимакского союза племен с середины IX до середины XI в., по-новому представляет социально-экономический строй кимакского общества, этногеографию кимакского объединения. Эта весьма интересная работа, фундированная ценным материалом, является как бы основой для продолжения изучения кимако-кыпчакской истории в последующие века, а именно в XI-XIII вв.

В монографии «К этнической истории узбекского народа» К.Ш. Шаниязов исследует историю кыпчаков как одного из основных компонентов в сложении узбекского народа. Работа в основном построена на историко-этнографическом материале; автор изучает историю той части кыпчаков, которые вследствие бурных событий послемонгольского времени ушли из Дешт-и Кыпчака в Среднюю Азию, где постепенно переходили к оседлости, теряя свои родовые и племенные названия и сливаясь с местными земледельческими группами населения. В то же время вся первая глава книги К.Ш. Шаниязова посвящена описанию общей картины истории кыпчаков - с первых известий об их появлении на исторической арене вплоть до монгольского нашествия. В этой главе дана историография кыпчакского вопроса и все факты традиционной исторической жизни кыпчаков в том виде, в котором она сейчас зафиксирована в русско-советской исторической науке. 
В последние годы появились исследования А.Ш. Кадырбаева, посвященные роли тюркоязычных народов, прежде всего кыпчаков, в этнической, культурной и политической жизни средневекового Китая.

Вопросам происхождения кыпчаков, степени и формы их участия в этногенезе многих тюркоязычных народов Южной и Западной Сибири посвящены работы Д.Г. Савинова, многие годы занимающегося изучением истории древних народов Южной Сибири в древнетюркскую эпоху по данным письменных источников и археологических изысканий. Д.Г. Савинов считает, что южные районы Западной Сибири были одной из основных областей кыпчакского этногенеза на всех этапах его развития.

Остальные немногочисленные исследования по истории кыпчаков, живших на территории Казахстана, предпринимались, как правило, в фрагментарном, справочном виде. В данном случае активом для любого исследователя кыпчакской проблемы могут быть имеющиеся переводы из различного круга источников, в основном восточных, и комментарии к ним, а также небольшие по объему исследования, выполненные учеными разных поколений, среди которых можно назвать имена В.В. Бартольда, В.Ф. Минорского, П. Пелльо, Д.А. Расовского, К. Цегледи, К. Менгеса и некоторых других.

О взаимоотношениях кыпчаков и Хорезма специальных работ нет вообще. Лишь в капитальном труде В.В. Бартольда «Туркестан в эпоху монгольского нашествия» затрагиваются некоторые стороны политических взаимоотношений хорезмшахов и кыпчаков. Они не могут, разумеется, воссоздать общей картины развития кыпчакского общества Казахста- на на протяжении даже сравнительно большого хронологического периода, сколь бы ни была велика их ценность в решении того или иного конкретного вопроса. Поэтому в исторической литературе по этому периоду еще много нерешенных вопросов. Среди них одним из важных является проблема взаимоотношений кыпчаков с крупнейшим государством Средней Азии, каким стал Хорезм в начале II тыс. н.э.

Взаимоотношения Хорезма и племен Дешт-и Кыпчака являются частью кардинальной проблемы, играющей большую роль в изучении этнических процессов региона, где издревле устанавливались постоянные связи населения земледельческих оазисов со скотоводческим тюрко-язычным кочевым населением Дешт-и Кыпчака в предмонгольское время.

Следует отметить, об этом упоминал и С.М. Ахинжанов, что слабость источниковедческой базы и малоизученность исследуемой проблемы, к сожалению, не позволили рассмотреть все затронутые в монографии проблемы, многие из них только поставлены. Однако исследование в целом дает представление об основных этапах этнической и политической истории кыпчаков Казахстана в эпоху средневековья.

Между тем, научные поиски C.M. Ахинжанова, учителями которого были выдающиеся ученые Л.Р. Кызласов в МГУ и А.Х. Маргулан в годы аспирантуры в Институте истории, археологии и этнографии им. Ч.Ч. Валиханова, всегда отличались новизной подходов к проблемам археологии, тщательностью аргументов в доказательстве тех, либо иных, зачастую спорных, положений. 
Еще студентом C.M. Ахинжанов увлекался проблемами неолита Северного Казахстана, а будучи уже известным кыпчаковедом, работал в Отраре, где вел раскопки разновременных памятников, в том числе и соотносимых с кангюями - предками кыпчаков.

Империя Кангюй - владение Кангу-Тарбан - Кыпчакскос государство - Казахское ханство - свидетельство политогенеза Государственности на территории Казахстана, этногенеза казахов.

С 1990 г. Сержан Мусатаевич занял должность заместителя начальника экспедиции по составлению Свода памятников истории и культуры Казахстана.

В сфере его научных интересов было исследование Великого Шелкового пути, он изучал древние города на юге Казахстана и в Жетысу (Ceмиречье), участвовал в международных экспедициях, в том числе и экспедиции ЮНЕСКО «СТепной путь» в 1991 г., выступал с яркими докладами на симпозиумах и конференциях по тематике диалога культур и цивилизаций на Шелковом пути.

Что бы ни делал С.М. Ахинжанов, все у него получалось талантливо, ярко, увлекательно. Его любили, ему подражали и не случайно «Ахинжановские чтения», которые ежегодно проводятся с 1993 года, привлекают внимание ученых разного возраста, пользуются популярностью.

Тематика чтений различна - это и вопросы изучения культур каменного века, исследования памятников эпохи бронзы и раннего железа, древних тюрок и урбанизации. Они собирают широкий круг участников из Казахстана, России, стран Средней Азии и дальнего зарубежья.

«Ахинжановские чтения» стали своеобразным полигоном для молодых исследователей, где они зачастую впервые приобретают опыт публичных выступлений, участия в научных дискуссиях [Заседание..., 1993; Акынжан, 2017; Байпаков, 2017]. Публикация материалов «Ахинжановских чтений» - это хорошая возможность молодым исследователям заявить о себе в науке. За прошедшие годы возмужали в научном отношении молодые исследователи, которые делали доклады и сообщения, участвовали в дискуссиях первых чтений, многие стали кандидатами наук, среди них есть и доктора наук. Главное - «Ахинжановские чтения» продолжают лучшие научные традиции казахстанской археологии, в развитии достижений которой принимал активное участие Сержан Мусатаевич Ахинжанов.

C.M. Ахинжанов - автор более 50 научных и научноисследовательских работ по истории средневековья и археологии Казахстана. В том числе одной из ярких фундаментальных его работ является монография «Кыпчаки в истории средневекового Казахстана», которая принесла автору широкую известность.

Умер Сержан Мусатаевич Ахинжанов в 1991 г., похоронен в г. Алматы. 


\section{Список основных трудов С.М. Ахинжанова}

\section{Автореферат:}

Ахинжанов С.М. Кипчаки и их политические взаимоотношения с Хорезмом в XI - начале XIII в.: автореф. дис. ... канд. ист. наук. Алма-Ата, 1973.

\section{Монографии:}

Кыпчаки в истории средневекового Казахстана. Алма-Ата: Наука, 1989. 293 c.

Кыпчаки в истории средневекового Казахстана / Под ред. К.М. Байпакова. Алматы: Гылым, 1995. 296 с. 2-е изд.

Кыпчаки в истории средневекового Казахстана. Алматы: Ғылым, 1999. 296 с. Изд. испр.

\section{Главы в книгах:}

Памятники эпохи бронзы. Белокаменка // Археологические памятники в зоне затопления Шульбинской ГЭС. Алма-Ата: Наука, 1987. С. 34 (в соавт. с А.Г. Максимовой, А.С. Ермолаевой).

Памятники средневековых кочевников. Темир-Канка II // Археологические памятники в зоне затопления Шульбинской ГЭС. Алма-Ата: Наука, 1987. С. 132-135 (в соавт. с Ю.И. Трифоновым).

Памятники средневековых кочевников. Белокаменка // Археологические памятники в зоне затопления Шульбинской ГЭС. Алма-Ата: Наука, 1987. С. 141-143 (6 соавт. с Ю.И. Трифоновым, А.С. Ермолаевой).

Памятники средневековых кочевников. Акчий III // Археологические памятники в зоне затопления Шульбинской ГЭС. Алма-Ата: Наука, 1987. С. 168-176 (в соавт. с Ю.И. Трифоновым).

Этнокультурная принадлежность памятников средневековых кочевников // Археологические памятники в зоне затопления Шульбинской ГЭС. Алма-Ата: Наука, 1987. C. 243-246.

Заключение // Археологические памятники в зоне затопления Шульбинской ГЭС. Алма-Ата: Наука, 1987. С. 274-276.

\section{Статьи:}

О внешнем облике кипчаков-половцев // Письменные памятники и проблемы истории культуры народов Востока. Краткое содержание докладов V годичной научной сессии ЛО ИВ АН. Май 1969 года. Л., 1969. С. 40-42.

Кыпчаки и Хорезм в канун Монгольского нашествия // Вестник АН КазССР. 1970. № 1. С. 45-49.

К вопросу о происхождении канов на Сырдарье // Известия АН КазССР. Сер. общ. наук. 1972. № 2. С. 64-69 (в соавт. с Л.Б. Ерзаковичем).

Из истории взаимоотношений кипчаков и Хорезма в XII - начале XIII века // Археологические исследования в Казахстане. Алма-Ата: Наука, 1973. С. 59-70.

К вопросу о знаках на керамике позднесредневекового Отрара // Древности Казахстана. Алма-Ата: Наука, 1975. С. 49-59.

Об этническом составе кыпчаков средневекового Казахстана // Прошлое Казахстана по археологическим источникам. Алма-Ата: Наука, 1976. С. 81-93.

Об этнической принадлежности каменных изваяний в «трёхрогих» головных уборах из Семиречья // Археологические памятники Казахстана. Алма-Ата: Наука, 1978. C. $65-79$. 
Савельева T.B. Ахинжанов Сержан Мусатаевич: к 80 -летию со дня рождения

Из истории движения кочевых племен евразийских степей в первой половине XI века // Археологические исследования древнего и средневекового Казахстана. Алма-Ата: Наука, 1980. С. 46-53.

Этнонимы «кимак» и «кипчак» // Археология эпохи камня и металла Сибири. Новосибирск, 1983. С. 106-122.

Исследование каменной крепости в Каратау // АО-1982. М.: Наука, 1984. C. 150 .

К происхождению и этнической атрибуции погребальных памятников Верхнего Прииртышья VIII-X вв. // Этническая история тюркоязычных народов Сибири и сопредельных территорий: тез. докл. обл. науч. конф. по антропологии, археологии и этнографии. Омск, 1984. С. 156-181 (в соавт. с Ю.И. Трифоновым).

Кимаки - уран-каи (Уранкаи) // ИККНАЯО. Тез. докл. ХХІХ сессии Постоянной междунар. алтаистической конф. М., 1986. Т. 1. С. 77-79.

Этногенетические процессы на территории Казахстана в конце I тыс. н.э. (кимаки и кипчаки) // Проблемы этногенеза и этнической истории народов Средней Азии и Казахстна. М., 1990. Вып. ІІ. С. 106-117.

К истории скотоводства и охоты в Казахстане (по остеологическому материалу из археологических памятников энеолита и бронзы). Алматы: Ғылым, 1992. 218 с. (в соавт. с Т.Н. Нурумовым, Л.А. Макаровой).

Древние караванные пути кимаков // Историко-культурное наследие кимаков и кипчаков / Павлодар. гос. ун-т им. С. Торайгырова [сост. Н.Е. Кузембаев]. Павлодар: ЭКО, 2006. С. 12.

К вопросу о происхождении канов на Сырдарье // Историко-культурное наследие кимаков и кипчаков / Павлодар. гос. ун-т им. С. Торайгырова [сост. Н.Е. Кузембаев]. Павлодар: ЭКО, 2006. С. 13-18 (в соавт. с Л.Б. Ерзаковичем).

Из истории взаимоотношений кипчаков и Хорезма в XII - начале XIII века // Историко-культурное наследие кимаков и кипчаков / Павлодар. гос. ун-т им. С. Торайгырова [сост. Н.Е. Кузембаев]. Павлодар: ЭКО, 2006. С .19-27.

Об этнической принадлежности каменных изваяний в «трехрогих» головных уборах из Семиречья // Историко-культурное наследие кимаков и кипчаков / Павлодар. гос. ун-т им. С. Торайгырова [сост. Н.Е. Кузембаев]. Павлодар: ЭКО, 2006. C. 28-37.

Этнонимы «кимчак» и «кипчак» // Историко-культурное наследие кимаков и кипчаков / Павлодар. гос. ун-т им. С. Торайгырова [сост. Н.Е. Кузембаев]. Павлодар: ЭКО, 2006. С. 38-47.

Кипчаки в X-XIII вв.: историографический обзор // Историко-культурное наследие кимаков и кипчаков / Павлодар. гос. ун-т им. С. Торайгырова [сост. Н.Е. Кузембаев]. Павлодар: ЭКО, 2006. С. 48-57.

\section{ЛИТЕРАТУРА}

1. Акынжан (Ахинжанова) Л. Археолог Сержан Ахинжанов. Имя на Шелковом пути // Археологическое наследие Центрального Казахстана: изучение и сохранение: сб. научн. ст., посвящ. 70-летию ЦКАЭ АН Казахстана / отв. ред. А.З. Бейсенов, В.Г. Ломан. Алматы: НИЦИА «Бегазы-Тасмола», 2017. Т. 1. С. 181-185.

2. Байпаков K.M. Сержан Ахинжанов - выдающийся археолог и востоковед Казахстана // Археологическое наследие Центрального Казахстана: изучение и сохранение: сб. научн. ст., посвящ. 70-летию ЦКАЭ АН Казахстана / отв. ред. А.З. Бейсенов, В.Г. Ломан. Алматы: НИЦИА «Бегазы-Тасмола», 2017. Т. 1. С. 174-180.

3. Заседание Института археологии, посвященное памяти С.М. Ахинжанова // Известия НАН РК. Сер. обществ. наук. 1993. № 5 (191). С. 92. 


\section{Сведения об авторе:}

Савельева Тамара Владимировна - доктор исторических наук, главный научный сотрудник, Институт археологии им. А.Х. Маргулана (г. Алматы, Казахстан); tsavelieva@mail.ru

\section{АҚЫНЖАНОВ СЕРЖАН МҰСАТАЙҰЛЫ: туғанына 80 жыл толуына орай}

\section{Т.В. Савельева}

Сержан Мұсатайұлы Ақынжанов 1939 жылы Алматы қаласында дүниеге келген. 1957 жылы орта мектепті бітіргеннен кейін С.М. Киров атындағы Қазақ мемлекеттік университетінің тарих факультетіне оқуға түседі де, екінші курстан соң М.В. Ломоносов атындағы Москва мемлекеттік университетінің археология кафедрасына ауыстырылады. 1964 ж. Сержан Мұсатайұлы университеттің тарих факультетін «археология» мамандығы бойынша үздік бітіреді. Мамандық бойынша тәлімгері және дипломдық жұмысының жетекшісі танымал ғалым Л.Р. Кызласов болды.

C.M. Ақынжанов Қазақ КСР ҒА Ш. Уәлиханов атындағы Тарих, археология және этнография институтының аспирантурасына түсіп, білім алуын одан әрі жалғастырады. 1968 ж. аспирантураны бітірген жас маман ҚазКСР ҒА ТАЭИ-ның ортағасырлар тарихы бөлімінде қалдырылады. 1969 ж. С.М. Ақынжанов археология бөліміне ауыстырылып, Отырар қаласын зерттеуге белсене араласады. 1973 ж. C.M. Ақынжанов «Қыпшақтар және олардың XI-XIII ғғ. Хорезммен саяси қарымқатынасы» тақырыбындағы кандидаттық диссертациясын қорғайды. 1984 жылдан бастап Сержан Мұсатайұлы археологиялық технологиялар лабораториясының меңгерушісі болды.

Түйін сөздер: археология, С.М. Ақынжанов, қыпшақтар

\section{AKHINJANOV SERJAN M.: to the 80th anniversary since birth}

\section{T.V. Savelyeva}

Serjan M. Akhinjanov was born in 1939 in Alma-Ata. After graduation of high school in 1957 he entered the Kazakh State University of S.M. Kirov to the department of history, from the second year he was transferred to Lomonosov Moscow State University to the department of archaeology. In 1964 Serjan M. graduated with honors from the department of history of the University majoring in "archaeology". A famous scientist L.R. Kyzlasov was his mentor in the specialty and a head of the thesis.

S.M. Akhinjanov continued training, having entered the postgraduate study at the Ch.Ch. Valikhanov Institute of history, archaeology and ethnography of the Academy of Science of Kazakh SSR. In 1968, after graduation from postgraduate study, a young scientist was left at the Institute of History, Archaeology and Ethnology of the Academy of Science of KazSSR to work in the department of medieval history. In 1969 S.M. Akhinjanov was transferred to the department of archaeology where he took active part in the research of ancient settlement Otrar. In 1973 S.M. Akhinjanov defended the master's thesis on a subject: "Cumans and their political relationship with Khwarezm in the 11-13th centuries". Since 1984 Serjan M. began to manage laboratory of archaeological technology.

Keywords: archaeology, S.M. Akhinjanov, cuman 


\section{REFERENCES}

1. Akynzhan (Ahinzhanova), L. 2017. In. Beisenov, A. Z., Loman, V. G. (eds.). Arheologicheskoenasledie CentralnogoKazahstana:izuchenieisohranenie(Archaeological heritage of Central Kazakhstan: study and protection), 1. Almaty: "Begazy-Tasmola" Publ., 181-185 (in Russian).

2. Baipakov, K. M. 2017. In. Beisenov, A. Z., Loman, V. G. (eds.). Arheologicheskoe nasledie Centralnogo Kazahstana: izuchenie i sohranenie (Archaeological heritage of Central Kazakhstan: study and protection), 1. Almaty: "Begazy-Tasmola" Publ., 174-180 (in Russian).

3. 1993. In Izvestiya NAN RK. Ser. obshchestv. Nauk (Proceedings of the National Academy of Sciences of the Republic of Kazakhstan), 5 (191), 92 (in Russian).

\section{About the Author:}

Savelyeva Tamara V. Doctor of Historical Sciences, Chief Researcher, A.Kh. Margulan Archeology Institute, Almaty, Kazakhstan; tsavelieva@mail.ru

\footnotetext{
Мүдделер қақтығысы туралы ақпаратты ашу. Автор мүдделер қақтығысының жоқтығын мәлімдейді. / Раскрытие информации о конфликте интересов. Автор заявляет об отсутствии конфликта интересов.

Disclosure of conflict of interest information. The author claim no conflict of interest.

Мақала туралы ақпарат / Информация о статье / Information about the article.

Редакцияға түсті / Поступила в редакцию / Entered the editorial office: 11.06.2019.

Рецензенттер мақұлдаған / Одобрено рецензентами / Approved by reviewers: 06.03.2019.

Жариялауға қабылданды / Принята к публикации / Accepted for publication: 13.03.2019.
} 